\title{
ARTIKELEN
}

\section{Belemmeringen bij de aanpak van onregelmatigheden door de curator}

\author{
Jessie Pool, Helen Pluut \& Reinout Vriesendorp
}

\section{Introductie}

Het beperken van de maatschappelijke schade die voortvloeit uit faillissementen waarbij zich onregelmatigheden ${ }^{1}$ hebben voorgedaan staat al decennia bovenaan de politieke agenda. ${ }^{2}$ De afgelopen jaren stond het publieke debat omtrent het bestrijden van onregelmatigheden voorafgaand aan en tijdens het faillissement in het teken van een principiële discussie tussen de wetgever en de faillissementspraktijk. De wetgever ziet in de curator de aangewezen persoon om onregelmatigheden aan te pakken door tijdige signalering en redressering daarvan. De curator heeft immers vergaande bevoegdheden in een faillissement, waardoor hij op een relatief eenvoudige manier onregelmatigheden in faillissementen zou kunnen opsporen én voert in de praktijk doorgaans al een oorzaken- of rechtmatigheidsonderzoek naar eventuele onregelmatigheden uit. ${ }^{3}$ In 2017 heeft de wetgever met de Wet versterking positie curator de rol van de curator op het gebied van het aanpakken van onregelmatigheden geïnstitutionaliseerd. ${ }^{4}$ Deze wet legt de curator de taak op om een oorzakenonderzoek te doen naar onregelmatigheden die het faillissement (mede) hebben veroorzaakt of het tekort in de boedel hebben vergroot (de signalering) en verplicht de curator geconstateerde onregelmatigheden vervolgens te melden bij de rechter-commissaris om eventuele vervolgstappen in het kader van een aansprakelijkstelling of fraudemelding te bespreken (de redressering). Deze signalerings- en redresseringstaak wordt ook wel de fraudesignalerende rol van de curator genoemd, ook al wordt beoogd om onregelmatigheden in brede zin aan te pakken. ${ }^{5}$

1 Een verzamelterm voor zowel frauduleuze handelingen als paulianeuze of onrechtmatige handelingen zoals onbehoorlijk bestuur. Zie ook Hilverda 2012a, p. 3, waar faillissementsfraude wordt gedefinieerd als handelingen waardoor schuldeisers zijn benadeeld. Frauduleus handelen is dus een van de vormen van onregelmatigheden.

2 Zie bijv. de brief van minister Opstelten waarin het belang van bestrijding van onregelmatigheden in faillissementen wordt benadrukt en waarin de reeds genomen maatregelen worden samengevat (Kamerstukken II 2012/13, 29911, nr. 52 en 74), de invoering van het civielrechtelijk bestuursverbod (Kamerstukken II, 34011) en de invoering van de wettelijke bewijsvermoedens van art. 2:138/248 BW in 1980 (zie Harmsen 2015, nr. 3.2.1 en de aldaar besproken parlementaire geschiedenis).

3 Kamerstukken II 2014/15, 34253, nr. 3, p. 3, 13.

4 Kamerstukken II 2014/15, 34253.

5 Zie ook Kamerstukken II 2013/14, 34011, nr. 3 en 4. 
Het doel van de wettelijke institutionalisering van de fraudesignalerende rol van de curator is uiteindelijk om onregelmatigheden rondom faillissement te voorkomen. De wetgever neemt dan ook aan dat de curator in voorkomend geval onregelmatigheden consequent zal aanpakken. Van een signalerende curator moet immers een zekere preventieve werking uitgaan, waardoor malafide bestuurders een drempel zouden ervaren om onregelmatig te handelen. ${ }^{6}$ De faillissementspraktijk heeft echter forse kritiek geuit op de wettelijk vastgelegde rol van de curator bij het aanpakken van onregelmatigheden. Hoewel de curator inderdaad in het kader van een oorzaken- of rechtmatigheidsonderzoek bekijkt of sprake is van gedragingen die de schuldeisers hebben beperkt in hun verhaalsmogelijkheden, betekent een algemene rol in de aanpak van onregelmatigheden een verzwaring van de taak van de curator. Een onderzoek naar onregelmatigheden is bovendien volgens menig curator niet per definitie in het belang van de gezamenlijke schuldeisers en kan dus zorgen voor potentiële tegenstrijdige belangen. ${ }^{7}$ Risico bestaat dan ook dat de curator zijn rol om onregelmatigheden aan te pakken niet in ieder faillissement uitvoert, hetgeen haaks staat op de aanname van de wetgever.

Uit eerder empirisch onderzoek blijkt dat (een signalering van) onregelmatigheden inderdaad vaak niet resulteren in een actie door de curator. ${ }^{8}$ Gebrek aan verhaal wordt veelal als logische verklaring genoemd voor het achterwege blijven van actie, ${ }^{9}$ maar hoe groot het effect van deze factor daadwerkelijk is, blijft onduidelijk. Daarnaast worden in de literatuur andere verklaringen genoemd, zoals het ontbreken van opvolging aan fraudemeldingen ${ }^{10}$ en de lege-boedelproblematiek. ${ }^{11}$ Dit soort verklaringen wordt echter nauwelijks onderbouwd en zijn verouderd of methodologisch ontoereikend. ${ }^{12}$ Grondig empirisch onderzoek naar factoren die de aanpak van onregelmatigheden door de curator kunnen beïnvloeden, ontbreekt.

Het doel van dit artikel is om die kennisleemte langs twee wegen op te vullen. Enerzijds door via een kwantitatieve analyse van faillissementsverslagen te onderzoeken of verhaal daadwerkelijk zo'n grote rol speelt in de geopenbaarde verantwoording van de besluitvorming van de curator en anderzijds om door een kwalitatieve analyse van interviews met curatoren meer inzicht te verkrijgen in de handelwijze van curatoren bij (vermoedelijke) onregelmatigheden. Naast het

$6 \quad$ Kamerstukken II 2012/13, 33695, nr. 1, p. 6.

7 Zie bijv. het leeuwendeel van de reacties op de consultatie van het Civielrechtelijk Bestuursverbod (via www.internetconsultatie.nl/civielbestuursverbod/reacties); Lennarts 2013; Keijzer 2015; Van Nielen 2016.

$8 \quad$ Knegt e.a. 2005, par. 6.1.2; Luttikhuis \& Timmermans 2007, par. 5.2.

9 Knegt e.a. 2005, par. 6.1.2; Luttikhuis \& Timmermans 2007, par. 5.2. Zie ook De Ridder e.a. 2019.

10 Lieferink 2020, p. 20-21 en 25 e.v.; De Ridder e.a. 2019, p. 57. Zie ook Feenstra 2019, p. 275-276.

11 Van Dijck e.a. 2008; Lieferink 2020, p. 20 e.v.; De Ridder e.a. 2019, par. 3.2 en par. 4.2.

12 Zie Lieferink 2020 (waar de steekproef klein is); De Ridder e.a. 2019 (waar de steekproef eveneens klein is en het doel van het onderzoek gericht was op een evaluatie van de garantstellingsregeling). Zie voor oudere onderzoeken: Van Dijck e.a. 2008; Knegt e.a. 2005; Luttikhuis \& Timmermans 2007. 
inzicht dat deze studie biedt in de praktijk van de aanpak van onregelmatigheden door de curator, kunnen de resultaten ook bijdragen aan nadere onderbouwing omtrent het rendement van de fraudesignalerende rol van de curator. Eventuele door dit onderzoek geïdentificeerde problemen kunnen de basis vormen voor een effectiever systeem voor de aanpak van onregelmatigheden rondom faillissementen.

In dit artikel bespreken wij allereerst de potentiële strijdige belangen die spelen bij de aanpak van onregelmatigheden door de curator (par. 2). Vervolgens doen we achtereenvolgens verslag van de kwantitatieve (par. 3) en de kwalitatieve empirische studie (par. 4) waarmee we meer inzicht verschaffen in de factoren die de curator belemmeren of aanmoedigen bij de aanpak van onregelmatigheden. In paragraaf 5 concluderen we, gaan we in op enkele normatieve implicaties van de resultaten van het onderzoek en doen we enkele aanbevelingen voor nader onderzoek.

\section{Belangenpluralisme bij de aanpak van onregelmatigheden}

Bij de uitoefening van zijn taken komt de curator een grote mate van beleidsvrijheid toe. ${ }^{13}$ In de praktijk komt de curator door zijn positie en rol in aanraking met tal van partijen en heeft hij rekening te houden met verschillende, soms tegenstrijdige, belangen. Richtsnoer is dat de curator handelt in het belang van de boedel, hetgeen samenvalt met het belang van zowel de gezamenlijke als de individuele schuldeisers. ${ }^{14}$ De curator dient daarnaast waar mogelijk rekening te houden met maatschappelijke belangen. ${ }^{15}$

Onderdeel van het afwikkelen van het faillissement in het belang van de gezamenlijke schuldeisers is het reconstrueren van de boedel. ${ }^{16}$ Dit betekent dat de curator ernaar streeft de boedel zo veel mogelijk (terug) te brengen in de staat waarin deze zou verkeren als bepaalde onregelmatige gedragingen niet zouden hebben plaatsgevonden. De reconstructietaak van de curator ligt in het verlengde van de taak om een zo hoog mogelijke boedelopbrengst te realiseren. ${ }^{17}$ Het staat de curator in beginsel vrij om te beoordelen of een bepaalde actie in het belang is van de gezamenlijke schuldeisers. ${ }^{18}$ Ook indien kennelijk onbehoorlijk bestuur een gegeven lijkt, kan de curator om proceseconomische redenen afzien van het instellen van een actie. ${ }^{19}$ Logisch gevolg van de reconstructietaak is dat de

13 HR 19 april 1996, NJ 1996/727 (Maclou); HR 16 december 2011, NJ 2012/515 (Prakke/Gips). Zie ook Verstijlen 2020, par. 2.

14 Zie ook Verstijlen 1998, p. 105-107.

15 HR 16 december 2011, NJ 2012/515 (Prakke/Gips). Zie ook Verstijlen 1998, p. 155; HR 19 december 2003, NJ 2004/293 (Mobell/Interplan). Zie over de afweging tussen het maatschappelijk belang en het belang van de gezamenlijke schuldeisers ook De Kloe 2020; Van Hees 2004.

16 Wibier 2018, nr. 50; Verstijlen 1998, p. 46. Zie ook INSOLAD Praktijkregels curatoren, art. 5.1.

17 Verstijlen 1998, p. 117.

18 Verstijlen 1998, p. 129-136; Vriesendorp 2013, nr. 243. Zie ook INSOLAD Praktijkregels curatoren, art. 4.1.

19 Borrius 2015, nr. 2.4. 
mogelijkheden van de curator om onregelmatigheden te redresseren slechts een middel zijn om de boedel te vergroten en geen doel op zich. Waar bij de reconstructie van de boedel de nadruk vooral ligt op het herstel van de verhoudingen en schadeloosstelling, is de nadruk bij de fraudesignalerende rol gelegen in het sanctioneren van gedrag dat tot die onregelmatigheden heeft geleid. Het sanctioneren van dergelijk gedrag is op zichzelf dan niet langer altijd een middel om de boedel te vergroten, maar wordt een opzichzelfstaand doel. De belangen die gepaard gaan met dit doel kunnen strijdig zijn met de belangen van de boedel en de belangen van de gezamenlijke schuldeisers.

Vanuit de curator bezien kunnen deze potentiële tegenstrijdige belangen als gevolg hebben dat de curator onregelmatigheden alleen aanpakt indien hij daarmee de belangen van de gezamenlijke schuldeisers kan dienen. Al tijdens de consultatiefase van de Wet versterking positie curator is naar voren gebracht dat de taak om onregelmatigheden aan te pakken strijdig kan zijn met de taak van de curator om het faillissement met een zo hoog mogelijke opbrengst (dus zo min mogelijk verspilde uitgaven) af te wikkelen in het belang van de gezamenlijke schuldeisers. ${ }^{20}$ Verschillende auteurs menen dat de fraudesignalerende taak moet worden gezien als een verlengde van de primaire taak van de curator, wat betekent dat voor de curator alleen een verplichting bestaat om onregelmatigheden aan te pakken indien de gezamenlijke schuldeisers door die onregelmatigheden zijn benadeeld in hun verhaalsmogelijkheden en zijn acties dat nadeel wegnemen. De curator is immers geen politieagent of boevenvanger. ${ }^{21}$ Er zijn echter ook auteurs die de fraudesignalerende taak zien als een maatschappelijke rol die de wetgever heeft toegewezen aan de curator en die losstaat van het boedelbelang. Een lege boedel en gebrek aan verhaal kan in deze zienswijze dan ook geen argument zijn om onregelmatigheden niet aan te pakken. ${ }^{22}$ Waar in ieder geval consensus over bestaat, is dat de primaire taak van de curator in sommige gevallen strijdig kan zijn met een algemene onderzoeksplicht of een meld- of aangifteplicht. $^{23}$

Daarnaast bestaat bij de aanpak van onregelmatigheden ook een potentiële strijdigheid met het eigen financiële belang van de curator. Als een oorzakenonderzoek per saldo verlies oplevert voor de boedel en er onvoldoende geld is om het salaris van de curator te voldoen, draagt de curator dat tekort. Zijn salaris wordt immers betaald uit de boedel. Een van de gevolgen van deze wijze van beloning is dat de curator een rechtstreeks belang heeft bij het vergroten van de boedel, althans zolang deze onvoldoende geld bevat om zijn salaris en onkosten te voldoen. Een dergelijke situatie doet zich voor in bijna $20 \%$ van de faillissementen. ${ }^{24}$ Vanuit zijn persoonlijke financiële belang heeft de curator dus een prikkel om zo veel mogelijk opbrengsten voor de boedel te realiseren. ${ }^{25}$ Deze prikkel heeft in het

20 Zie bijv. Van Nielen \& Derijks 2014, p. 26; Van Enckevort 2016, par. 4.2; Lennarts 2013.

21 Van Enckevort 2016; Vriesendorp 2017.

22 Hilverda 2014, p. 12; Van Nielen \& Derijks 2014, p. 31; Vermaire \& Luijkx 2016.

23 Zie de hiervoor besproken literatuur.

24 Zie Van Elswijk e.a. 2016, par. IV.1.

25 Art. 71 Fw. Zie ook Franken e.a. 2008, voorwoord, waarin de totstandkoming van de salariëring wordt besproken. 
kader van de aanpak van onregelmatigheden een belangrijke keerzijde. Aangezien de curator wordt betaald uit de boedel, bestaat het risico dat de curator niet altijd een gedegen onderzoek doet naar onregelmatigheden indien zijn beloning in het gedrang komt, bijvoorbeeld als er sprake is van een lege boedel en/of een gebrek aan verhaalsmogelijkheden. ${ }^{26}$

Het door de wetgever met de Wet versterking positie curator beoogde doel wordt dus mogelijk niet bereikt, doordat het aanpakken van onregelmatigheden ten koste kan gaan van zowel het belang van een zo hoog mogelijke boedel voor schuldeisers als van de eigen portemonnee van de curator.

\section{De aanpak van onregelmatigheden kwantitatief onderzocht}

\subsection{Onderzoeksopzet}

Het doel van het kwantitatieve onderzoek is het onderzoeken van de relatie tussen onregelmatigheden en verhaal enerzijds en de beslissing van de curator om onregelmatigheden aan te pakken anderzijds. Op basis van zowel het wettelijke instrumentarium dat de curator ter beschikking staat als de taak van de curator op het gebied van het redresseren van onregelmatigheden, verwachten we dat de curator in ieder faillissement waar onregelmatigheden zijn gesignaleerd actie onderneemt. Om die reden luidt onze eerste hypothese als volgt:

Hypothese 1: Er bestaat een positieve samenhang tussen gesignaleerde onregelmatigheden en de waarschijnlijkheid van redressering door de curator in faillissementen.

Door de mogelijke tegenstrijdigheid tussen het belang van de gezamenlijke schuldeisers en het financiële belang van de curator enerzijds en de taak om onregelmatigheden aan te pakken anderzijds, verwachten we echter ook dat de beslissing van de curator om actie te ondernemen afhangt van verhaalsmogelijkheden. Om die reden luidt de tweede hypothese als volgt:

Hypothese 2: Er bestaat een negatieve samenhang tussen gebrek aan verhaalsmogelijkheden en de waarschijnlijkheid van redressering door de curator in faillissementen.

Hypothese 2 ziet op het verband tussen gebrek aan verhaalsmogelijkheden en redressering. Naast dit directe verband verwachten we ook dat gebrek aan verhaalsmogelijkheden een effect heeft op de relatie tussen gesignaleerde onregelmatigheden en redressering. Dat wil zeggen dat we verwachten dat gesignaleerde onregelmatigheden minder vaak worden aangepakt indien er twijfels zijn geuit over verhaalsmogelijkheden dan wanneer deze twijfels niet door de curator worden vermeld. Om die reden luidt onze derde hypothese als volgt: 
Hypothese 3: Gebrek aan verhaalsmogelijkheden matigt het verband tussen onregelmatigheden en de waarschijnlijkheid van redressering door de curator zodanig dat onregelmatigheden minder invloed hebben op de redresseringsbeslissing als de bestuurders geen verhaal bieden.

\section{- Steekproef}

Om de relatie tussen de variabelen te onderzoeken, zijn 2134 faillissementsverslagen onderzocht. Faillissementsverslagen zijn in beginsel verplicht in ieder faillissement en de laatste jaren vrij toegankelijk via het Centraal Insolventieregister (CIR) waarin ieder faillissement gedurende de looptijd in Nederland is opgenomen. ${ }^{27}$ Het CIR heeft echter geen zoekfunctie waarmee beëindigde faillissementen kunnen worden gefilterd. Bovendien zijn faillissementsverslagen in het CIR slechts toegankelijk tot maximaal zes maanden na beëindiging van het faillissement, waardoor geen grote dataset kan worden verkregen van reeds enige tijd geleden afgeronde faillissementen. Om die reden is een steekproef gebruikt bestaande uit verslagen van faillissementen die zijn beëindigd tussen april 2018 en december $2018 .^{28}$ Deze startdatum is gekozen omdat vanaf april 2018 in vrijwel alle faillissementen een gestandaardiseerd faillissementsverslag werd gebruikt, waardoor de faillissementsverslagen eenvoudig doorzoekbaar en vergelijkbaar zijn. De einddatum is gebaseerd op praktische overwegingen, waaronder de tijd die nodig was om de faillissementsverslagen handmatig te coderen. ${ }^{29}$

Om inzicht te krijgen in de factoren die van invloed zijn op de redresseringsbeslissing van de curator, is gekeken naar de gestandaardiseerde paragrafen in het faillissementsverslag waar de curator het oorzaken- en rechtmatigheidsonderzoek beschrijft (par. 1.7 en 7). De inhoud van deze twee paragrafen is gecodeerd om tot een overzicht te komen van de geïdentificeerde typen onregelmatigheden, een eventueel gebrek aan verhaalsmogelijkheden en de redresseringsacties die zijn ingezet door de curator. ${ }^{30}$

\section{- Variabelen}

De afhankelijke variabele is redressering door de curator. Redressering is iedere actie van de curator die is bedoeld om gesignaleerde onregelmatigheden aan te

27 Art. 73a Fw en https://insolventies.rechtspraak.nl/\#!/zoeken/index.

28 De dataset is beschikbaar gesteld door Raimond Dufour, www.failimprove.nl en www. schuldeisersbelang.nl. De dataset is gebaseerd op publiekelijk toegankelijke faillissementsverslagen die automatisch werden opgeslagen in een database. De volgende informatie is beschikbaar gesteld van elk faillissement: 1) startdatum van het faillissement, 2) einddatum van het faillissement, 3) insolventiekenmerk, 4) bedrijfsnaam, 5) rechtsvorm, 6) KvK-nummer, 7) aantal medewerkers op datum faillissement, 8) rechtbank, 9) curator, 10) link naar de oorspronkelijke vindplaats van het verslag, 11) paragraaf 'oorzaken' en 12) paragraaf 'rechtmatigheid'.

29 Dit betekent dat de wettelijke institutionalisering van de fraudesignalerende rol van de curator in art. $68 \mathrm{Fw}$ niet op alle faillissementen van toepassing was. De fraudesignalerende rol bestond echter ook al voor de wettelijke institutionalisering. Om aan deze beperking tegemoet te komen zijn aanvullend interviews uitgevoerd.

30 De auteurs bedanken Susan van den Dool en Sofia de Jong voor hun bijdragen aan het coderen. De coderingen zijn steekproefsgewijs gecontroleerd, waarbij geen grote afwijkingen zijn geconstateerd. 
pakken. De variabele is geoperationaliseerd als een binaire variabele $(0=$ geen redressering, 1 = redressering). De variabele redressering is onder te verdelen in de verschillende vormen van redressering, te weten schikking, bestuurdersaansprakelijkheidsprocedure, pauliana-actie, fraudemelding en/of aangifte.

De twee belangrijkste onafhankelijke variabelen zijn 'onregelmatigheid' en 'gebrek aan verhaalsmogelijkheden'. De binaire variabele 'onregelmatigheid' geeft aan of de curator in het faillissementsverslag heeft aangegeven een onregelmatigheid te hebben gesignaleerd ( 0 = geen onregelmatigheid, 1 = onregelmatigheid). Er is vervolgens onderscheid gemaakt tussen vier onregelmatigheden, te weten de binaire variabelen '(kennelijk) onbehoorlijk bestuur' (art. 2:9, 6:162 en/of 2:138/248 BW), 'schending van de administratieplicht' (art. 2:10 BW), 'schending van de deponeringsplicht' (art. 2:394 BW) en 'frauduleus handelen' (zowel strafrechtelijk als civielrechtelijk). Bij de andere variabele geldt dat we op basis van eerder onderzoek vooral geïnteresseerd zijn in het effect van een 'gebrek aan verhaalsmogelijkheden' en om die reden is dit gebruikt als referentiecategorie voor deze binaire variabele. ${ }^{31}$ De variabele is gecodeerd als 1 wanneer in het faillissementsverslag expliciet werd gesproken over het gebrek aan verhaal, met letterlijke bewoordingen of met frases die duiden op een gebrek aan verhaal (bijv. 'een succesvolle actie kan niet leiden tot een verhaalbare vordering'). Idealiter zou het onderzoek situaties waarin de bestuurder geen verhaal bood, vergelijken met situaties waarin de bestuurder wel verhaal bood. De expliciete benoeming van het bestaan van verhaalsmogelijkheden kwam echter nauwelijks voor $(n=14)$. Hoewel het aannemelijk is dat er verhaalsmogelijkheden bestaan wanneer de curator het gebrek aan verhaalsmogelijkheden niet expliciet benoemt of actie onderneemt, kunnen we niet overtuigend stellen dat het niet noemen van het gebrek aan verhaal altijd het bestaan van verhaalsmogelijkheden impliceert. In de praktijk zijn er ook curatoren die in actie komen zonder dat op dat ogenblik het bestaan van verhaalsmogelijkheden al vaststaat. Om die reden hebben we ervoor gekozen om deze categorie als 'overig' te bestempelen. Het onderzoek vergelijkt dan ook situaties waarin sprake was van een gebrek aan verhaalsmogelijkheden met situaties waarin dergelijke zorgen niet werden benoemd in het faillissementsverslag.

\section{- Beschrijvende statistieken}

In tabel 1 staan enkele beschrijvende statistieken van de variabelen. In 45,2\% van alle onderzochte faillissementen heeft de curator onregelmatigheden geconstateerd. Dit getal sluit aan bij eerder onderzoek waaruit lijkt te volgen dat onregelmatigheden veel voorkomen. ${ }^{32}$ De curator heeft onregelmatigheden geredresseerd in $28,7 \%$ van de onderzochte faillissementen. Deze percentages laten zien dat de curator gesignaleerde onregelmatigheden niet consequent aanpakt. In

31 Knegt e.a. 2005, par. 6 en par. 8.6; Luttikhuis \& Timmermans 2007, par. 5.2; Lieferink 2020, p. 20 e.v.

32 Van Elswijk e.a. 2016, par. 5.2. Zie voor eenzelfde conclusie over 2010: Boer \& Lalta 2011. Zie Vriesendorp 2017 voor enkele opmerkingen over de in dat onderzoek gebruikte term onregelmatigheden. 
Tabel 1 Descriptieve statistieken van de variabelen*

\begin{tabular}{lllll}
\hline Variabele & N & Aantal (I) & Aantal (0) & \% (I) \\
\hline Onregelmatigheden & 1815 & 820 & 995 & 45,2 \\
(Kennelijk) onbehoorlijk bestuur & 1765 & 549 & 1216 & 31,1 \\
Schending van de administratieplicht & 1772 & 408 & 1364 & 23,0 \\
Schending van de deponeringsplicht & 1760 & 505 & 1255 & 28,7 \\
Frauduleus handelen & 1773 & 101 & 1672 & 5,7 \\
Gebrek aan verhaalsmogelijkheden & 1780 & 375 & 1405 & 21,1 \\
Redressering & 1772 & 509 & 1263 & 28,7 \\
\hline
\end{tabular}

* De variabelen '(kennelijk) onbehoorlijk bestuur', 'schending van de administratieplicht', 'schending van de deponeringsplicht' en 'frauduleus handelen' kunnen tegelijk voorkomen. Om die reden is de variabele 'onregelmatigheden' geen som van de genoemde variabelen.

\section{Tabel 2 Redresseringsratio per onregelmatigheid*}

\begin{tabular}{lll}
\hline & Aantal & Redressering \\
\hline Onregelmatigheden & 793 & $368(46 \%)$ \\
(Kennelijk) onbehoorlijk bestuur & 536 & $310(58 \%)$ \\
Schending van de administratieplicht & 396 & $209(53 \%)$ \\
Schending van de deponeringsplicht & 488 & $169(35 \%)$ \\
Frauduleus handelen & 98 & $88(90 \%)$ \\
Geen onregelmatigheden & 967 & $130(13 \%)$ \\
\hline
\end{tabular}

* Het aantal onder 'onregelmatigheden' verschilt van tabel I, omdat tabel 2 alleen de gevallen laat zien met een waarde voor redressering.

$21,1 \%$ van de gevallen werd door de curator vastgesteld dat er geen verhaalsmogelijkheden zouden zijn voor een eventuele vordering.

Alle variabelen bevatten enkele zogenoemde missing cases. Deze missing cases kunnen worden verklaard, doordat sommige faillissementsverslagen niet het standaardformat hebben gevolgd, waardoor de alinea's over het oorzaken- en rechtmatigheidsonderzoek niet in de dataset zijn opgenomen en dus niet konden worden gecodeerd.

Tabel 2 geeft inzicht in de redresseringsratio's per gesignaleerde onregelmatigheid. In slechts $46 \%$ van de gevallen waarin de curator onregelmatigheden heeft gesignaleerd, is ook actie ondernomen. Opvallend is dat curatoren consequenter zijn in het redresseren van geconstateerde fraude (90\%). Een uitgebreidere beschrijving van de resultaten volgt na een uitleg van de gebruikte analysemethodes. 


\section{- Analyse}

De nominale variabelen in het onderzoek zijn gebaseerd op dichotome gegevens en vertegenwoordigen geen numerieke waarde. Om die reden gebruiken we de Pearson's chi-square test om te bepalen of er een significant verband bestaat tussen twee categorische variabelen en de Cramér's V statistic om informatie te verkrijgen over de sterkte van de samenhang. Deze bivariate analyses geven inzicht in de samenhang van iedere aparte variabele met de redresseringsbeslissing van de curator.

Om de hypothesen met betrekking tot de invloed van onregelmatigheden en gebrek aan verhaalsmogelijkheden te testen, gebruiken we een multivariate regressieanalyse, die de samenhang tussen een onafhankelijke variabele en de afhankelijke variabele schat en daarbij controleert voor een aantal andere variabelen. Onze afhankelijke variabele is zoals aangegeven een binaire variabele, namelijk of de curator in een bepaald faillissement heeft besloten onregelmatigheden te redresseren (waarde 1 ) of niet (waarde 0 ). Om die reden gebruiken we een binaire logistische regressieanalyse om de waarschijnlijkheid van redresseringsacties te relateren aan de onafhankelijke variabelen. Een significantieniveau van $\alpha=0,05$ is voor alle statistische testen gebruikt.

$\mathrm{Bij}$ het interpreteren van de uitkomsten van het logistische regressiemodel maken we gebruik van de odds ratio. In de analyses wordt een onafhankelijke variabele gerelateerd aan de relatieve kans op redressering (waarde $=1$ ), oftewel de waarschijnlijkheid van redressering ten opzichte van de waarschijnlijkheid dat de curator geen stappen onderneemt om onregelmatigheden te redresseren. Die verhouding in kansen noemen we de odds. De odds ratio geeft vervolgens de samenhang weer met de onafhankelijke variabele. Wanneer we bijvoorbeeld onregelmatigheid als voorspellende variabele relateren aan redressering, vergelijken we de zogenaamde odds van situaties met en zonder onregelmatigheid. De odds ratio wordt uitgedrukt in een waarde tussen 0 en oneindig, waarbij een odds ratio van 1 betekent dat er geen samenhang is tussen de onafhankelijke en de afhankelijke variabele.

\subsection{Resultaten}

We hebben geconstateerd dat onregelmatigheden in minder dan de helft van de gevallen (46\%) worden aangepakt. Ons doel is om dit gebrek aan redresseringsacties te verklaren. De resultaten van het onderzoek laten zien dat onregelmatigheden wel degelijk sterk positief samenhangen met redressering $\left(\chi^{2}(1)=233,3, p<\right.$ $\left.0,001, \Phi_{\text {Cramer }}=0,36\right) .{ }^{33}$ Voor de verschillende vormen van onregelmatigheden hebben we tevens significante en sterke samenhang gevonden met redressering. De samenhang tussen redressering en de variabelen (kennelijk) onbehoorlijk bestuur $\left(\chi^{2}(1)=336,8, p<0,001\right.$, $\left.\Phi_{\text {Cramer }}=0,44\right)$, schending van de administratieplicht $\left(\chi^{2}(1)=157,2, p<0,001, \Phi_{\text {Cramer }}=0,30\right)$, en frauduleus handelen $\left(\chi^{2}\right.$ $\left.(1)=193,3, p<0,001, \Phi_{\text {Cramer }}=0,33\right)$ zijn matig tot sterk. De correlatie tussen

33 De sterkte van de samenhang is gebaseerd op de waarden van Cohen. Een waarde onder de 0,3 is zwak, een waarde tussen de 0,3 en 0,5 is middelmatig en een waarde van boven de 0,5 is sterk. Zie Cohen 1988, p. 215 e.v. 
schending van de deponeringsplicht en redressering is ook significant, maar tussen de twee variabelen bestaat slechts een zwakke samenhang $\left(\chi^{2}(1)=15,4, p<\right.$ $\left.0,001, \Phi_{\text {Cramer }}=0,10\right)$. Ook de samenhang tussen gebrek aan verhaalsmogelijkheden en redressering $\left(\chi^{2}(1)=11,4, p<0,001, \Phi_{\text {Cramer }}=0,08\right)$ is significant, maar zwak.

Naast bivariate analyses hebben we ook een multivariate regressieanalyse gebruikt om de gecombineerde effecten van de variabelen op redressering te bepalen. De resultaten van de binaire logistische regressie (tabel 3; model 1) laten zien dat zowel de variabele onregelmatigheden $(b=1,83, p<0,001)$ als gebrek aan verhaalsmogelijkheden $(b=-0,35, p<0,005)$ samenhangt met de waarschijnlijkheid van redressering. De odds ratio $\left(\mathrm{e}^{b}\right)$ is 6,3 voor onregelmatigheden en 0,7 voor gebrek aan verhaalsmogelijkheden. Meer specifiek betekent dit dat de waarschijnlijkheid van redressering bij gesignaleerde onregelmatigheden meer dan 6 keer zo groot is als de waarschijnlijkheid wanneer geen onregelmatigheden zijn gesignaleerd. Wanneer de curator twijfelt over de verhaalsmogelijkheden, is de waarschijnlijkheid van redressering bijna anderhalf keer lager dan wanneer de curator dergelijke zorgen niet in het faillissementsverslag benoemt. Deze resultaten ondersteunen zowel hypothese 1 als 2. Onregelmatigheden lijken een hogere voorspellende waarde te hebben dan gebrek aan verhaalsmogelijkheden en er is dus geen bewijs gevonden voor de aanname dat gebrek aan verhaal een dominante reden is om niet te redresseren. De gevonden waarde voor de Nagelkerke $R^{2}$ laat tevens zien, dat gesignaleerde onregelmatigheden en gebrek aan verhaalsmogelijkheden de redresseringsbeslissing niet volledig verklaren. ${ }^{34}$

We hebben eerder gezien (tabel 2) dat er verschillen bestaan tussen de redresseringsratio's van de verschillende vormen onregelmatigheden. We hebben een logistische regressie uitgevoerd om de invloed van de verschillende typen onregelmatigheden tegelijkertijd te testen. De resultaten (tabel 3; model 2) wijzen op een significant verband tussen enerzijds (kennelijk) onbehoorlijk bestuur ( $b=2,45, p$ $<0,001)$, schending van de deponeringsplicht $(b=-0,65, p<0,001)$ en frauduleus handelen $(b=3,15, p<0,001)$ en anderzijds de waarschijnlijkheid van redressering. We zien dat de geschatte waarschijnlijkheid van redressering 11,5 keer zo groot is voor faillissementen waarin de curator (kennelijk) onbehoorlijk bestuur heeft gesignaleerd als voor faillissementen waarin hij dat niet heeft gesignaleerd. Voor frauduleus handelen geldt eveneens dat de geschatte waarschijnlijkheid van redressering 23,3 keer zo groot is bij een dergelijke constatering als wanneer de curator geen frauduleus handelingen heeft geconstateerd. Daarentegen maakt de constatering van de curator dat de deponeringsplicht is geschonden redressering minder waarschijnlijk: de waarschijnlijkheid was 1,9 keer kleiner dan wanneer de deponeringsplicht niet werd geschonden. We hebben geen significante relatie gevonden tussen schending van de administratieplicht $(b=0,33, p=0,072)$ en de

34 De Nagelkerke R squared zegt iets over de waarschijnlijkheid van een perfecte voorspelling. Een waarde van 1 betekent dat het zeer waarschijnlijk is dat de onderzochte variabelen de afhankelijke variabele volledig verklaren en voorspellen. Zie ook Nagelkerke 1991, p. 691-692. 
Tabel 3 Regressieanalyse met redressering als afhankelijke variabele†

\begin{tabular}{|c|c|c|c|c|c|c|c|c|c|}
\hline \multirow{2}{*}{$\begin{array}{l}\text { Onafhankelijke } \\
\text { variabelen }\end{array}$} & \multicolumn{3}{|c|}{ Model I } & \multicolumn{3}{|c|}{ Model 2} & \multicolumn{3}{|c|}{ Model 3} \\
\hline & b & SE & OR & b & SE & OR & b & SE & OR \\
\hline Onregelmatigheden & $1,83 * *$ & 0,13 & 6,25 & & & & $1,95 * *$ & 0,13 & 6,99 \\
\hline $\begin{array}{l}\text { (Kennelijk) } \\
\text { onbehoorlijk } \\
\text { bestuur }\end{array}$ & & & & $2,45 * *$ & 0,18 & 11,55 & & & \\
\hline $\begin{array}{l}\text { Schending van de } \\
\text { administratieplicht }\end{array}$ & & & & 0,33 & 0,18 & 1,39 & & & \\
\hline $\begin{array}{l}\text { Schending van de } \\
\text { deponeringsplicht }\end{array}$ & & & & $-0,65^{* *}$ & 0,16 & 0,52 & & & \\
\hline Frauduleus handelen & & & & $3,15 * *$ & 0,40 & 23,26 & & & \\
\hline $\begin{array}{l}\text { Gebrek aan verhaals- } \\
\text { mogelijkheden }\end{array}$ & $-0,35^{*}$ & 0,14 & 0,70 & $-1,17^{* *}$ & 0,19 & 0,31 & 0,48 & 0,33 & 1,62 \\
\hline $\begin{array}{l}\text { Onregelmatigheden } \times \\
\text { Geen verhaal }\end{array}$ & & & & & & & $-0,97 * *$ & 0,36 & 0,38 \\
\hline Nagelkerke $R^{2}$ & 0,187 & & & 0,351 & & & 0,192 & & \\
\hline
\end{tabular}

$\dagger$ Alleen ongestandaardiseerde coëfficiënten $(b)$ worden gerapporteerd voor de logistische regressiemodellen (model I, model 2 en model 3 ). $\mathrm{SE}=$ standaardafwijking, $\mathrm{OR}=$ odds ratio.

$* p<0,05 ; * *<<0,01$.

waarschijnlijkheid van redressering. Deze resultaten zijn niet consistent met de resultaten van de bivariate analyse, welke ook schending van de administratieplicht als significante voorspeller van redressering aanwees. Verschillen in resultaten kunnen worden verklaard door de aanwezigheid van controlevariabelen in de multivariate regressieanalyses. Dat wil zeggen dat de schattingen verwijzen naar de effecten van de ene factor, terwijl ze voor de invloed van een andere factor controleren (die wordt als het ware constant gehouden). Bovendien is er in deze analyse gecontroleerd voor gebrek aan verhaalsmogelijkheden, welke factor ook in dit model significant was $(b=-1,17, p<0.001)$. Hoewel de voorspellende waarde van dit model sterker is dan dat van model 1 , kunnen ook deze variabelen de redresseringsbeslissing niet volledig verklaren.

Model 1 en 2 kijken naar hoofdeffecten, waarbij wordt aangenomen dat het effect van de ene variabele onafhankelijk is van de waarden van een andere variabele die in het model is opgenomen. Om de derde hypothese met betrekking tot het interactie-effect tussen onregelmatigheden en het gebrek aan verhaalsmogelijkheden te testen, hebben we een productterm van de respectievelijke variabelen in het regressiemodel opgenomen (tabel 3; model 3). De resultaten wijzen op een significant interactie-effect $(b=-0,97, p<0,001)$. Het hoofdeffect van onregelmatigheden $(b=1,95, p<0,001)$ dient daarom geïnterpreteerd te worden in het licht van het significante interactie-effect.

De negatieve interactiecoëfficiënt impliceert dat de invloed van onregelmatigheden zwakker (dus minder positief) is wanneer twijfels bestaan over de verhaalsmogelijkheden. Anders gezegd: onregelmatigheden leiden minder vaak tot redressering wanneer geen of onvoldoende verhaal wordt geboden. Dit maken we 


\section{Figuur 1 De invloed van onregelmatigheden op de waarschijnlijkheid van} redressering naar verhaalsmogelijkheden*

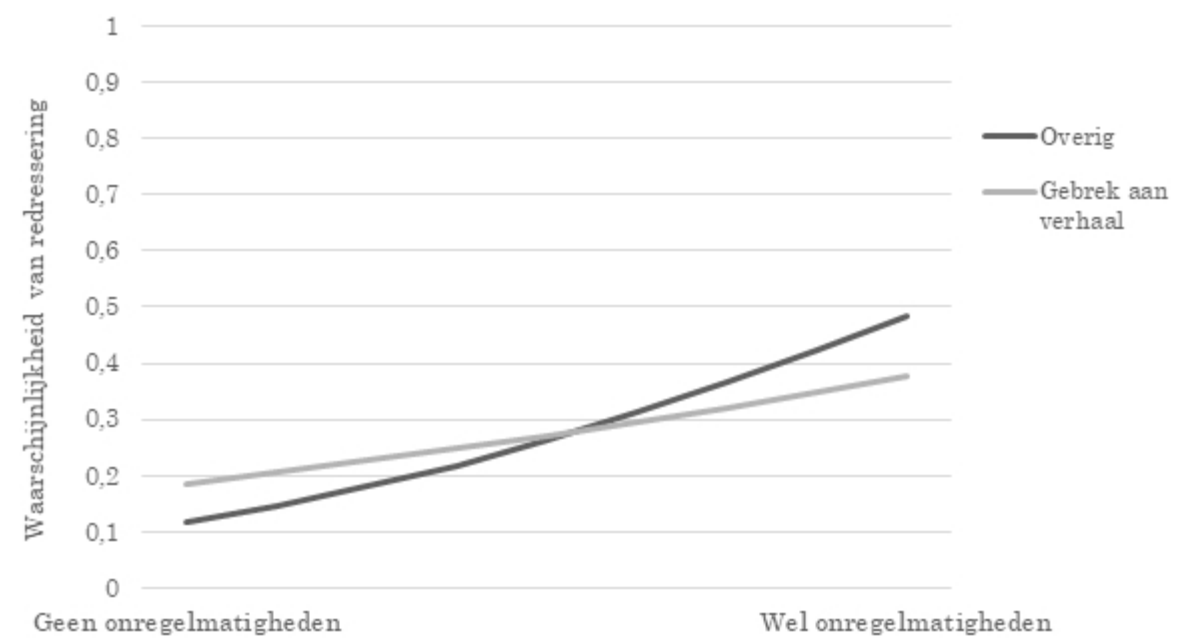

* De categorie 'overig' bestaat uit faillissementen waarin zorgen over verhaalsmogelijkheden niet werden benoemd in het faillissementsverslag.

inzichtelijk in figuur 1, waarin de invloed van waarschijnlijkheid van redressering wordt vergeleken voor de situatie waarin de curator aangaf zorgen te hebben over de verhaalsmogelijkheden met situaties waarin dergelijke zorgen niet werden benoemd. Uit figuur 1 is af te lezen dat onregelmatigheden positief verband houden met redressering (gezien de stijgende lijn) en dat dit verband minder sterk aanwezig is als er een gebrek aan verhaalsmogelijkheden is (gezien de minder steile helling van die lijn). Deze resultaten zijn in lijn met hypothese 3 . Het interactie-effect heeft er echter niet voor gezorgd dat de voorspellende waarde van het model groter is geworden.

Onze bevindingen suggereren dat verhaalsmogelijkheden een rol spelen bij de beslissing om gesignaleerde onregelmatigheden aan te pakken. Het effect van beschikbaarheid van verhaalsmogelijkheden is echter minder sterk dan verwacht. Ook de voorspellende waardes van de verschillende modellen geven aanleiding te veronderstellen dat er naast het ontbreken van verhaalsmogelijkheden andere redenen bestaan voor curatoren om geconstateerde onregelmatigheden niet te redresseren. In het kwalitatieve onderzoek gaan wij nader in op de vraag welke overige factoren een rol spelen bij de aanpak van onregelmatigheden. 


\section{Tabel 4 Overzicht participanten}

\begin{tabular}{lll}
\hline Arrondissement* & Ervaring & Kantoorgrootte \\
\hline Amsterdam $(n=8)$ & $0-5$ jaar $(n=5)$ & Klein $-1-50$ advocaten $(n=24)$ \\
Den Haag $(n=3)$ & $6-10$ jaar $(n=7)$ & Middel $-5 \mathrm{I}-100$ advocaten $(n=6)$ \\
Gelderland $(n=3)$ & II-I5 jaar $(n=7)$ & Groot $-10 \mathrm{I}$ of meer advocaten $(n=3)$ \\
Limburg $(n=2)$ & I6 of meer jaren $(n=14)$ & \\
Midden-Nederland $(n=5)$ & \\
Noord-Holland $(n=2)$ & \\
Noord-Nederland $(n=2)$ & \\
Oost-Brabant $(n=6)$ & \\
Overijssel $(n=2)$ & \\
Rotterdam $(n=4)$ & \\
Zeeland-West-Brabant $(n=2)$ & \\
\hline
\end{tabular}

* Enkele participanten zijn werkzaam (geweest) in meerdere arrondissementen.

\section{De aanpak van onregelmatigheden kwalitatief onderzocht}

\subsection{Onderzoeksopzet}

\section{- Steekproef}

Om inzicht te krijgen in het afwegingsproces van de curator om onregelmatigheden wel of niet aan te pakken, zijn semigestructureerde interviews uitgevoerd met 33 curatoren. ${ }^{35}$ Het samplingproces is tweeledig. Allereerst is op basis van een lijst van alle curatoren in Nederland $(N=610)$ een aantal curatoren geselecteerd. ${ }^{36}$ Bij de selectie is rekening gehouden met de gewenste variatie in arrondissement, aantal jaren werkervaring als advocaat en kantoorgrootte. ${ }^{37}$ De steekproef is zodanig samengesteld, dat alle relevante variaties een plek hebben gekregen in het onderzoek. ${ }^{38}$ Op basis van de analyse van de afgenomen interviews en daaruit verkregen informatie zijn aanvullende participanten geselecteerd. ${ }^{39}$ In tabel 4 staat een overzicht per rubriek van alle participanten.

\section{- Interviews}

De interviews zijn uitgevoerd op basis van een onderwerpenlijst. De eerste onderwerpenlijst is opgesteld op basis van eerder door een van de onderzoekers uitge2010, p. 9.

36 De curatorenlijst is opgesteld aan de hand van een lijst met kantoren met een curatorenpraktijk via www.curatoren.nl. Vervolgens is handmatig via de website van de desbetreffende kantoren onderzocht welke advocaten tevens curator zijn.

37 Deze samplingmethode staat beter bekend als purposeful sampling. Zie Webley 2010, p. 7.

38 Zie ook Remmers \& Groenland 2006.

39 Deze samplingmethode staat beter bekend als theoretical sampling. Zie Webley 2010, p. 7. 
voerde pilotinterviews en de bevindingen uit het kwantitatieve onderzoek. ${ }^{40}$ De onderwerpenlijst is twee keer gewijzigd. Zo kwamen tijdens eerdere interviews het benoemingsbeleid en de voorfinanciering naar voren als belangrijke aanvullende thema's. ${ }^{41}$ De meest recente topic list behandelt de volgende onderwerpen: 1) opleiding en ervaring, 2) benoeming door de rechtbank, 3) eerste contact met de bestuurder(s), 4) het oorzaken- en rechtmatigheidsonderzoek, 5) redressering bestuursnormen: schikking, procedure en fraudemelding, 6) artikel 68 Fw: de taak van de curator, 7) lege boedels, voorfinanciering en de garantstellingsregeling en 8) de rol van de rechter-commissaris. Tijdens de interviews werden per onderwerp open vragen gesteld om inzicht te krijgen in het afwegingsproces van de curator bij het signaleren en redresseren van onregelmatigheden. De duur van de interviews varieerde van 54 minuten tot 1 uur en 46 minuten. De interviews werden met toestemming opgenomen en anoniem getranscribeerd. ${ }^{42}$ Uiteindelijk heeft het dataverzamelingsproces geleid tot 572 pagina's aan transcripten.

\section{- Analyse}

De transcripten zijn gecodeerd met behulp van Atlas.ti. ${ }^{43}$ Het coderingsproces bestond uit drie fases. In de eerste fase, de open coding-fase, zijn de quotes uit de interviews gelabeld met codes die de inhoud van de quote beschrijven. Hierbij is constant comparison toegepast, hetgeen inhoudt dat bij het toewijzen van codes aan quotes steeds is gekeken of een bestaande code kon worden gebruikt of een nieuwe code moest worden gemaakt. ${ }^{44} \mathrm{Na}$ de open coding-fase, resulterend in 262 codes, zijn de codes gecategoriseerd in overkoepelende categorieën (de axial coding-fase) en is ten slotte bekeken hoe de verschillende categorieën van codes met elkaar verband hielden (selective coding-fase).

De data-analyse verliep gelijktijdig met de dataverzameling, waardoor analyses konden worden gebruikt om de onderwerpen en vragen in nieuwe interviews aan te scherpen. Door het toepassen van constant comparison kon worden gemonitord op welke punten voldoende informatie was verzameld en op welke punten tijdens de latere interviews nog extra doorgevraagd moest worden. Zodra duidelijk werd dat nieuwe interviews geen nieuwe informatie (codes) meer opleverden en het punt van saturatie was bereikt, is gestopt met het benaderen van participanten.

40 De onderwerpen kunnen dan ook worden beschouwd als sensitizing concepts. Zie Bowen 2006, p. 3.

41 De eerste versie van de topic list bestond uit de volgende onderwerpen: 1) opleiding en ervaring, 2) aanstelling als curator, 3) oorzakenonderzoek en art. $68 \mathrm{Fw}, 4$ ) beoordeling van bestuurlijk handelen, 5) schikking versus een procedure en 6) de rol van de rechter-commissaris. De tweede versie van de topic list bestond uit de volgende onderwerpen: 1) opleiding en ervaring, 2) aanstelling door de rechtbank, 3) eerste stappen na aanstelling, 4) art. 68 Fw, 5) beoordeling bestuurlijk handelen, 6) redressering bestuursnormen en 7) de rol van de rechter-commissaris.

42 De auteurs bedanken Sebastian Kingdon en Gijs de Koning voor hun bijdrage aan het transcriberen van de interviews.

43 Zie Saldaña 2013.

44 Zie ook Boeije 2002, p. 391-401. 
Figuur 2 Het afwegingsproces van de curator
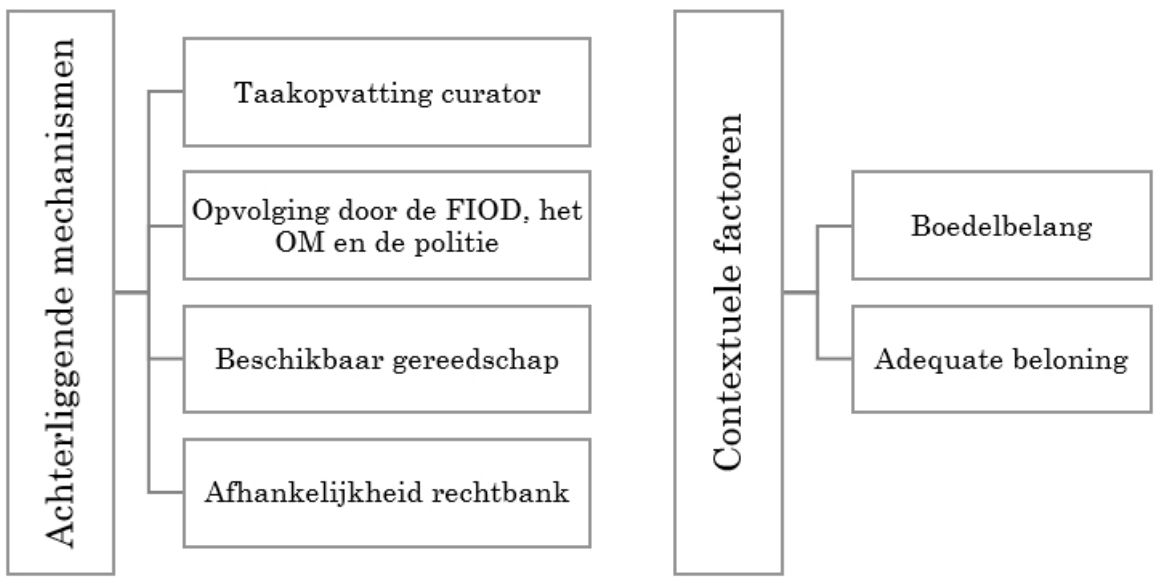

\subsection{Resultaten}

De analyse van de interviews heeft geleid tot vier achterliggende mechanismen en twee faillissementsafhankelijke contextuele factoren die van invloed zijn op de wijze waarop de curator afwegingen maakt bij de aanpak van onregelmatigheden. Een overzicht van de achterliggende mechanismen en contextuele factoren staat in figuur 2.

\section{- Taakopvatting curator}

Bij de wijze waarop curatoren aankijken tegen de taak om onregelmatigheden aan te pakken spelen vier achterliggende mechanismen. Hoe deze taak wordt opgepakt door een curator hangt allereerst samen met de wijze waarop de curator vindt dat invulling moet worden gegeven aan zijn taak. Onder de participanten bestaat grote eenduidigheid over de primaire taak, het behartigen van de belangen van de gezamenlijke schuldeisers. Niet alle participanten hebben echter dezelfde opvatting over de fraudesignalerende taak. Onder de participanten zijn ruwweg twee visies te onderscheiden.

De eerste groep curatoren is niet blij met de taak om onregelmatigheden aan te pakken.

'En natuurlijk de curator heeft daar een extra opdrachtje meegekregen dankzij Opstelten en zijn vriendjes. Maar wie is de curator om dat verder op te pakken en dat verder uit te zoeken, dat moet echt liggen bij de politie en het OM.'

'Het komt er allemaal een beetje bij, zoals de wetgever er wel meer taken bij heeft gepropt, waar niet iedereen heel gelukkig mee is volgens mij.'

'Weg ermee.' 
Deze quotes laten zien dat er onbegrip heerst over de fraudesignalerende taak van de curator. Sommige participanten zijn gefrustreerd over het 'afschuiven' van de faillissementsfraudebestrijding op een commerciële partij. Gevolg van het onbegrip en de onduidelijkheid over de reikwijdte van de taak is dat deze groep curatoren de taak om onregelmatigheden aan te pakken vooral als middel ziet om benadeling van schuldeisers ongedaan te maken.

'Ik doe het altijd in het belang van de boedel: het gaat om geld. En ik ben het niet helemaal eens geweest met al die wetswijzigingen van de laatste jaren in die zin dat wij geen fraudeopspoorder of politieagent zijn. Laat het OM dat maar lekker opknappen. Het gaat puur om het boedelbelang, het terughalen van dingen die weg zijn wat mij betreft.'

Deze groep curatoren pakt onregelmatigheden niet consequent en actief aan als de boedel er niet bij gebaat is. De meeste curatoren uit deze groep geven wel aan een fraudemelding te willen doen indien zij tegen frauduleuze handelingen aanlopen.

De tweede groep curatoren ziet de fraudesignalerende taak als part of the job.

'Natuurlijk is het zo dat er veel lege boedels zijn en dat je je af en toe zorgen maakt over de betaling van de curatorsalarissen, maar aan de andere kant heb je ook gekozen voor deze rol, je hoeft het niet te doen. Ik vind wel dat er standaardwerkzaamheden en standaarduren bij zijn en ik vind wel dat in ieder geval de fraudemelding erbij hoort.'

Deze groep participanten heeft veelal ook een persoonlijke overtuiging om boeven te vangen en onrechtmatig gedrag te sanctioneren.

'Wat dat betreft is mijn rechtvaardigheidsgevoel misschien iets te groot voor een curator. Maar ik kan er heel slecht tegen dat er hier in Nederland bestuurders zijn die, of het nou eenmalig is of meermalig, vennootschappen misbruiken ten behoeve van zichzelf. (...) Zo iemand moet aangepakt worden. (...) Ik wil niet die curator zijn die een faillissement afwikkelt en dan hoor ik heel vaak die zijn eigen zakken vult en vervolgens denkt dat was leuk, klaar! Ik wil die curator zijn die daadwerkelijk een bestuurder aanpakt. Maar ja, dat kan niet altijd.'

\section{- Opvolging van een fraudemelding}

Naast de taakopvatting van de curator speelt de wijze waarop opvolging wordt gegeven aan een fraudemelding mee als tweede achterliggend mechanisme voor de bereidheid van curatoren om onregelmatigheden aan te pakken. Tijdens de gesprekken werd duidelijk dat de opvolging vaak te wensen overlaat.

'En een ander punt vind ik dat de opvolging en het idee dat je het ergens voor doet, de terugkoppeling omtrent opvolging, die lijkt niet heel erg aanwezig te 
zijn. (...) Ik krijg niet de indruk dat daar echt iets mee gebeurt. Hier op kantoor roep ik weleens grappend, dat e-mailadres om fraude te melden is volgens mij gewoon een no-reply adres, dat het niet eens ergens terechtkomt. Alsof je een e-mail stuurt aan de kerstman of aan sinterklaas, dat er nooit wat mee gebeurt. Ik zet het iets te zwaar aan, Jessie, maar ik krijg niet het idee dat daar een opvolging op komt.'

Het gebrek aan opvolging is een frustratie voor curatoren en maakt dat zij minder geneigd zijn om een fraudemelding te doen of zelfs om onderzoek te doen naar onregelmatigheden als de boedel er niet bij gebaat is. Positieve ervaringen zijn schaars.

\section{- Beschikbaar gereedschap}

Een derde achterliggende belemmering die curatoren aandragen is het beschikbare gereedschap om onregelmatigheden daadwerkelijk te kunnen aanpakken. Veel curatoren vinden het frustrerend dat zij onregelmatigheden niet altijd kúnnen aanpakken. Zij geven aan het gevoel te hebben dat al hun inzet voor niets is, aangezien ze niet geëquipeerd zijn om dat te doen en echte fraudeurs slim genoeg zijn om weg te komen met hun onrechtmatige gedrag.

'Sommigen die voelen dat dan als een roeping ineens, die denken van: nou moeten we het gaan doen, wij zijn hét. Wij zijn het niet, je hebt helemaal niks. Je hebt een kantoortje, je hebt wat papier en een e-mailaccount. Dan ben je curator, dan kan je heel hard gaan zwaaien met je tekst en commentaar maar die gasten trekken zich daar helemaal niks van aan. Die hebben wietplantages, schulden. Dat is helemaal niet iets voor ons, we zijn gewoon eenvoudige afwikkelaars van een failliete boedel. Ik vind ook echt dat de overheid ons daar niet mee mag opzadelen, ja mag wel maar dan moeten we ook een organisatie daaromheen kunnen bouwen om daarop toegerust te zijn. (...) Nou dan wil ik graag een dienstpistool, dan wil ik ook de machtiging om mensen te arresteren, mee te nemen, hier op kantoor in een celletje te plaatsen.'

\section{- Afhankelijkheid van de rechtbank}

De relatie met de rechtbank is als laatste achterliggende mechanisme van invloed op de wijze waarop curatoren invulling geven aan de taak om onregelmatigheden aan te pakken. Volgens curatoren hebben sommige rechters-commissarissen fraudebestrijding als speerpunt.

'Ik weet nog goed, toen ik een keer een faillissement kreeg overgedragen van een vertrekkende kantoorgenoot. Toen zei de RC tegen mij - toen ik het wilde afwikkelen - oké maar heeft u ook hier en hier naar gekeken, want misschien moeten we wel een fraudemelding doen.'

Het benoemingsbeleid en het gebrek aan transparantie bij de beoordeling en aanstelling van curatoren blijkt voor veel curatoren een lastig punt te zijn. Curatoren zijn door hun afhankelijkheid van de rechtbank voor hun aanstellingen geneigd 
om suggesties van de rechters-commissarissen op te volgen en stellen vaker voor een fraudemelding te doen als zij weten dat de toezichthoudende rechter-commissaris fraudebestrijding belangrijk vindt.

De relatie tussen de curator en de rechter-commissaris blijkt een gevoelig gespreksonderwerp voor curatoren. Sommige curatoren vroegen voorafgaand aan de beantwoording van de interviewvragen over de relatie met de rechter-commissaris nogmaals om bevestiging van anonimiteit en bij het controleren van de transcripten hebben curatoren veelvuldig passages geschrapt waarin zij zich kritisch uitlaten over de rechtbank. De gevoeligheid lijkt te zijn gelegen in het feit dat de rechter-commissaris ook broodheer is van de curator.

'Het heeft toch ook wel weer te maken - en dat is misschien een hele flauwe reden - dat je bij de rechtbank en bij de rechters-commissarissen er ook niet heel slecht op wilt staan als je het elke keer niet doet. En ook niet doorpakt als daar wel een aanleiding toe is. En dat kan ook wel weer vervelende consequenties hebben bij de verdeling van faillissementen die wel wat ondoorzichtig is, waar we het eerder al over hadden. Ik denk dat dat misschien ook wel meespeelt bij het functioneren van een curator. Als je nooit een fraudemelding doet terwijl de rechter-commissaris vindt dat daar wel aanleiding toe is, dan - ik kan niet overzien of de rechtbank daar consequenties aan verbindt maar ik kan me wel voorstellen dat ze daar niet zo heel blij mee zijn.'

\section{- Boedelbelang}

Naast de vier hierboven genoemde achterliggende mechanismen die voor iedere curator - afhankelijk van eerdere ervaringen - verschillend zijn, zijn ook twee factoren van belang die in de context van een bepaald faillissement meespelen. Allereerst baseert de curator zijn inzet om onregelmatigheden aan te pakken op het belang van zijn acties voor de boedel. De curator is constant bezig met een kosten-batenanalyse.

'Aan het eind van de rit moet het zo zijn dat de kans dat de boedel er baat bij heeft gehad, aanmerkelijk is. Dat is de afweging die je moet maken. Als je het vanuit principes doet, of omdat het een lul is of weet ik het wat, dat zijn geen goede redenen om te overwegen om te gaan procederen. (...) Je doet het voor de crediteuren, die moeten er baat bij hebben en niet omdat jij principieel vindt dat je die man of die vrouw het leven zuur moet maken. Er moet onderaan de streep voor jouw crediteuren geld binnenkomen.'

De kosten-batenanalyse laat zien dat curatoren hun werkzaamheden uiteindelijk primair verrichten ten behoeve van de gezamenlijke schuldeisers. Het gewicht dat wordt gegeven aan het boedelbelang in de kosten-batenanalyse is ook een verklaring waarom curatoren niet snel extra werk verrichten voor de aanpak van onregelmatigheden of een bestuursverbod vorderen, een ander recent wettelijk instrument (art. 106a Fw) om onregelmatigheden te bestrijden. 
'Natuurlijk spelen er ook andere belangen, maatschappelijke belangen en zo, maar de kern is nog steeds de gezamenlijke schuldeisers. Maar de gezamenlijke schuldeisers hebben natuurlijk er verder niks aan op het moment dat een bestuurder een bestuursverbod krijgt omdat zij het leed al hebben. Dus alleen toekomstige schuldeisers hebben er baat bij. Dat is voor mij ook een overweging om niet altijd - en ik heb het tot op heden ook niet gedaan hoor - een bestuursverbod te vorderen.'

\section{- Adequate beloning}

Naast het boedelbelang speelt als tweede contextuele factor in bepaalde faillissementen het persoonlijke financiële belang van curatoren een rol. Curatoren worden betaald uit de boedel en bij een lege boedel krijgen zij dus geen vergoeding voor de gemaakte uren.

'Wat dat betreft - en dat zeg ik ook maar tegen jou - we werken allemaal bij commerciële kantoren, dus die commerciële kantoren hebben ook de faillissementspraktijk omdat het geld oplevert voor de kantoren, het is gewoon omzet. Maar als curator heb je natuurlijk een boedelbelang en dat is tegenstrijdig met het belang van jouw kantoor. Kantoor wil - in theorie natuurlijk - geld verdienen en omzet behalen, terwijl jij als curator een boedelbelang hebt en dus gewoon moet kijken naar dat boedelbelang en als dat zegt dat verdere kosten niet meer gemaakt moeten worden, dan moeten verdere kosten niet meer gemaakt worden. (...) Ik denk dat het iets is wat wel speelt, ja. En ik denk dat niemand daar open en eerlijk over zal zijn.'

'Kantooromzet speelt ook wel mee. Ik heb daar ook weleens over nagedacht, als een kantoorgenoot van mij in die zaak werkzaamheden verricht - en dan is het zo dat zij op basis van hun plek op de curatorenlijst voor die uren salaris krijgen - maar ons commerciële uurtarief is lager dan de Recofa uurtarieven. Dat betekent dat als ik een kantoorgenoot, die ook op lijst 3 staat, mij bij laat staan in een grote bestuurdersaansprakelijkheidsprocedure - hij heeft hetzelfde uurtarief als ik terwijl hij eigenlijk commercieel een lager uurtarief heeft. Als ik dat extern zou doen, kan ik een kantoor zoeken met een lager uurtarief en daar zou de boedel profijt van kunnen hebben. Maar ik weet het niet helemaal zeker, want misschien is die kwaliteit minder. Het is wel zo dat je onder één dak zit en informatie kan uitwisselen. Even overleggen. Maar, dat is dus wel een - ik weet zeker dat dat voor alle kantoren speelt, die omzetkwestie. En zeker bij kantoren waarbij de faillissementsafdeling ook binnen kantoor moet laten zien dat ze ook een goede business hebben. En ik heb dat meegemaakt bij [kantoor X]. Daar zat ik op een faillissementsafdeling en die moest dus binnen kantoor laten zien wat de omzet was. Er werd daar heel simpel gekeken naar 'je houdt zoveel plekken bezet, iedere plek kost geld en we willen dat je daar als insolventieafdeling ook aan bijdraagt'. En als je werk buiten kantoor gaat brengen dan is dat minder omzet, dus dat speelt gewoon mee.' 
Deze quotes laten zien dat curatoren afwegingen om onregelmatigheden aan te pakken wel degelijk baseren op hun eigen financiële belangen. Ook blijkt dat het uurtarief van curatoren buiten de grote en gespecialiseerde kantoren zodanig hoog ligt, dat zij onbetaald gebleven uren in lege boedels kunnen compenseren met de uren waarvoor zij wel een beloning ontvangen.

'Je weet gewoon dat je zelf van de tien faillissementen die je hebt, er vijf of zes zijn met een boedel erin. Maar goed, het uurtarief dat we hebben, met alle respect, maar wij zijn natuurlijk een klein kantoor en geen Zuidaskantoor, is 335 euro, het hoogste tarief. Mijn adviestarief is 265 euro per uur. Als ik het verlies verdisconteer, dan zit ik ongeveer op mijn normale tarief. Dat vind ik fantastisch.'

Opvallend is dat iedere curator ondanks bovengenoemde overwegingen aangaf zich niet te laten leiden door persoonlijke financiële prikkels als deze strijdig zijn met het belang van de gezamenlijke schuldeisers, maar wel collega-curatoren zei te kennen die wél gevoelig zijn voor perverse prikkels.

'Ik denk wel dat de tendens in Nederland is dat curatoren inderdaad hun zakken vullen over de rug van schuldeisers.'

'Ik vind dat een lege boedel niet de reden moet zijn voor een beslissing van een curator om een bepaalde handeling niet te doen. In het verlengde daarvan geldt dat curatoren niet - toevallig - moeten stoppen met hun acties als het boedelactief op is gegaan aan hun salaris. (...) In kleinere faillissementen is niet altijd zeker dat het salaris van de curator betaald kan worden. Als ik in rechtmatigheidsdiscussies bestuurders bijsta, dan valt mij wel eens op dat onderzoek wordt gedaan op kosten van de crediteuren, terwijl eventuele opbrengsten daarvan volledig of nagenoeg volledig opgaan aan het salaris van de curator. Soms proberen curatoren in dat soort gevallen schikkingen te treffen voor enkele tienduizenden euro's die (nagenoeg) volledig opgaan aan het salaris van de curator zelf. Natuurlijk is het niet zo dat dit nooit een gerechtvaardigd resultaat is. De wet bepaalt immers de volgorde waarin schuldeisers worden betaald. Toch vind ik van belang om met dit aspect en de publieke opinie daarover rekening te houden.'

'Er zijn best wel veel kantoren voor een groot gedeelte afhankelijk van de faillissementspraktijk. Die hebben hun praktijk zien leeglopen. Dus op het moment dat er dan een keer een faillissement is waar geld in te verdienen valt. En dat hoeft niet eens bewust te zijn he. Maar je kan bijvoorbeeld in plaats van een briefje één keer even te checken en doorlezen kan je hem twee keer doorlezen want je hebt de tijd toch. (...) Dus ik denk niet eens dat het uit kwade wil is maar dat het gebeurt, ik kan mij niet voorstellen dat dat niet zo is.' 


\section{Conclusie en discussie}

\subsection{Integratie van bevindingen}

Het doel van dit onderzoek was om inzicht te krijgen in factoren die van invloed zijn op de aanpak van onregelmatigheden door de curator, waarbij zowel kwantitatieve als kwalitatieve gegevens nodig waren. We hebben op basis van de kwantitatieve studie de aanname kunnen bevestigen dat curatoren gesignaleerde onregelmatigheden minder vaak redresseren indien er twijfels zijn over verhaalsmogelijkheden. Tegelijkertijd lieten de statistische analyses zien dat de invloed van verhaalsmogelijkheden op de redresseringsbeslissing minder groot was dan verwacht én dat deze factor niet volledig verklaart waarom geconstateerde onregelmatigheden niet consequent worden aangepakt.

We hebben op basis van de interviews inzicht geboden in het afwegingsproces van de curator, waardoor naast gebrek aan verhaalsmogelijkheden ook andere verklaringen voor het niet consequent aanpakken van onregelmatigheden boven water zijn gekomen. Uit de interviews blijkt dat niet iedere curator zich even hard inzet om onregelmatigheden aan te pakken. De mate van inzet baseren curatoren onder andere op de mate waarin zij zich gesteund voelen in hun fraudesignalerende rol. Zelfs curatoren die fraudesignalering zien als een belangrijke taak, laten zich ontmoedigen door het gebrek aan opvolging wanneer zij onregelmatigheden hebben gemeld of door het feit dat echte fraudeurs nog altijd vrij spel lijken te hebben. De rechter-commissaris speelt een belangrijke rol in het bemoedigen óf het ontmoedigen van de curator.

In faillissementen laten curatoren zich nog altijd het meest leiden door de belangen van de gezamenlijke crediteuren. Curatoren zijn veelal van mening dat fraudebestrijding niet in het belang is van de gezamenlijke schuldeisers en laten deze taak dan ook meestal achterwege als er geen kans bestaat op verhaal. Ook wegen curatoren mee of ze zelf wel voldoende beloning uit een specifiek faillissement kunnen halen. Uit de interviews blijkt dat de meeste curatoren zich niet actief zullen inzetten voor het aanpakken van onregelmatigheden wanneer daar geen adequate beloning voor bestaat.

De resultaten van de interviews geven tevens inzicht in belangrijke knelpunten in de relatie tussen de rechter-commissaris ${ }^{45}$ en de curator en de beloningsstructuur van curatoren. ${ }^{46}$

\subsection{Methodologische reflectie}

De gekozen opzet van het onderzoek brengt bepaalde beperkingen met zich mee. Allereerst zijn de resultaten van de kwantitatieve studie gebaseerd op een analyse van openbare faillissementsverslagen. Hoewel het openbare faillissementsverslag wordt gezien als een betrouwbare bron, ${ }^{47}$ is de inhoud op het gebied van onregelmatigheden slechts een zienswijze en daardoor niet altijd compleet of betrouw-

Deze knelpunten zijn algemeen van aard en passen niet in de context van dit artikel, maar zullen worden behandeld in vervolgwerk van onze hand. 
baar. De curator dient bovendien terughoudend te zijn met het doen van uitspraken over mogelijke onregelmatigheden. ${ }^{48}$ Indien de curator vermoedt dat sprake is van onregelmatigheden, maar hij door bijvoorbeeld het gebrek aan verhaalsmogelijkheden geen nader onderzoek doet en/of acties onderneemt, zal de curator het vermoeden van onregelmatigheden wellicht niet vermelden in het faillissementsverslag. ${ }^{49}$ Verwacht wordt dan ook dat de aantallen waarin de curator onregelmatigheden heeft gesignaleerd maar vervolgens niet heeft geredresseerd in werkelijkheid hoger liggen dan in deze studie is geconstateerd.

De tweede beperking is of de curator überhaupt toekomt aan het oorzakenonderzoek indien er een lege boedel is of indien er twijfels bestaan over de verhaalsmogelijkheden. De resultaten van het kwantitatieve onderzoek bieden geen inzicht in het onderzoek waarmee onregelmatigheden worden gesignaleerd, terwijl dit onderzoek een belangrijke schakel is in de aanpak van onregelmatigheden.

Het combineren van een statistische analyse en een gestructureerde analyse van interviews heeft belangrijke voordelen gehad. De resultaten van de kwalitatieve analyse hebben bijgedragen aan het interpreteren van de resultaten van de kwantitatieve analyse en hebben verdiepende inzichten geboden in de mechanismen achter de aanpak van onregelmatigheden door de curator. Toch kleven ook aan de kwalitatieve studie enkele beperkingen.

Ten eerste geven interviews slechts inzicht in percepties van curatoren en is niet onderzocht hoe curatoren daadwerkelijk handelen in bepaalde situaties. Onbekend is in hoeverre curatoren in het interview sociaal wenselijke antwoorden hebben gegeven. We hebben geprobeerd om dit te beperken door de participanten op hun gemak te stellen en verschillende controlevragen te stellen. ${ }^{50}$ Nader onderzoek - bijvoorbeeld experimenteel onderzoek - is nodig om te onderzoeken hoe curatoren daadwerkelijk handelen in specifieke situaties. Ook triangulatie door aanvullende interviews met bijvoorbeeld rechters-commissarissen te doen kan helpen om meer inzicht te krijgen in de handelwijze van curatoren bij het signaleren en redresseren van onregelmatigheden.

De kwalitatieve analyses zijn ten tweede niet geschikt om (causale) verbanden aan te tonen en die te generaliseren naar de volledige populatie van de huidige steekproef. ${ }^{51}$ Toch is geprobeerd om door het toepassen van een gestructureerde dataverzameling en analysemethode te komen tot resultaten die representativiteit benaderen. ${ }^{52}$ Door het bereiken van saturatie kunnen we aannemen dat sprake is van zogenoemde variatiedekkende generalisatie, waardoor het waarschijnlijk is dat de resultaten van het kwalitatieve onderzoek representatief zijn voor de Nederlandse curatorenpraktijk. ${ }^{53}$ Nader onderzoek - bijvoorbeeld in de vorm van een enquête - kan uitsluitsel geven over de samenhang tussen de gevonden belemmeringen enerzijds en de inzet van de curator om onregelmatigheden aan te pakken anderzijds. 


\subsection{Normatieve implicaties}

De resultaten van de studie geven inzicht in belemmeringen die de curator ervaart bij de aanpak van onregelmatigheden. Hieruit zijn de volgende aanbevelingen voor de wetgever en de faillissementspraktijk af te leiden.

\section{- Onduidelijkheid over de invulling van de fraudesignalerende rol}

De resultaten bevestigen dat de opvattingen over de reikwijdte van de fraudesignalerende rol van de curator binnen deze beroepsgroep sterk uiteenlopen. Het blijkt voor curatoren lastig in te schatten hoe de fraudesignalerende rol eenvormig zou moeten worden ingevuld. De verschillende opvattingen maken dat iedere curator de taak om onregelmatigheden aan te pakken invult op een wijze die aansluit bij zijn perceptie van de fraudesignalerende rol. De wettelijke regeling biedt de curator deze beleidsvrijheid. ${ }^{54}$ Door de verschillende manieren waarop curatoren onregelmatigheden aanpakken - variërend van alleen een onderzoek indien verhaalsmogelijkheden vooraf vaststaan tot te allen tijde een diepgaand onderzoek uitvoeren naar de daadwerkelijke oorzaken van het faillissement - kan getwijfeld worden aan het rendement en de preventieve werking van de fraudesignalerende rol van de curator. Ook zorgt de variatie in aanpak voor een scheve situatie voor schuldeisers, waarbij afhankelijk van de persoonlijke perceptie van de curator onderzoek wordt verricht op kosten van de boedel.

Onze aanbeveling is om na te denken over een nadere invulling van deze rol van de curator, bijvoorbeeld in de vorm van een onderzoeks- en redresseringsprotocol eventueel op te stellen door Insolad in samenspraak met Recofa, zodat curatoren de taak om onregelmatigheden te signaleren en redresseren op min of meer vergelijkbare wijze invullen.

\section{- De fraudesignalerende rol van de curator wordt ervaren als symboolpolitiek}

Ten tweede hebben curatoren sinds de inwerkingtreding van de Wet versterking positie curator het gevoel onderdeel te zijn van symboolpolitiek, omdat zij niet voldoende worden gefaciliteerd bij het aanpakken van onregelmatigheden. Zo blijkt uit de interviews dat het gebrek aan een structurele beloning een belangrijke reden is voor curatoren om af te zien van het aanpakken van onregelmatigheden. Voorts hebben curatoren soms onvoldoende instrumenten in hun gereedschapskist om onregelmatigheden effectief te kunnen aanpakken, waardoor de echte fraudeurs vrijuit gaan. De gebrekkige opvolging die door het OM, de FIOD en de politie wordt gegeven aan fraudemeldingen, versterkt het gevoel dat deze aan de curator opgedragen taak een uiting is van symboolpolitiek. ${ }^{55}$ Participanten die het gevoel hadden onderdeel te zijn van symboolpolitiek, waren minder geneigd onregelmatigheden aan te pakken.

Op basis van deze perceptie bevelen wij aan te onderzoeken of er manieren zijn om de curator beter te faciliteren bij de aanpak van onregelmatigheden. Dit kan bijvoorbeeld door te zorgen voor een vergoeding voor het uitvoeren van fraude-

54 Feenstra 2019, p. 275-276. Zie ook De Ridder e.a. 2019, p. 87-88.

55 Zie ook Bentfort van Valkenburg \& Van de Wiel 2020, par. 4.4; Van Nielen 2017; De Ridder e.a. 2019, p. 33-34. 
signalerende taken, het verbeteren van de opvolging die wordt gegeven door de daartoe aangewezen partijen bij een fraudemelding en door het wettelijke instrumentarium dat de curator ter beschikking staat om onregelmatigheden aan te pakken opnieuw onder de loep te nemen. ${ }^{56}$

\section{- Perverse prikkels: het salaris van de curator}

Het kwalitatieve onderzoek heeft ten derde inzicht gegeven in de rol die perverse prikkels kunnen spelen bij de werkzaamheden van de curator. Hieronder verstaan we prikkels waardoor curatoren in de belangenafweging eigen financiële belangen meer laten meewegen dan de belangen van de gezamenlijke schuldeisers of de belangen die zijn gemoeid met de aanpak van onregelmatigheden. Uit de interviews zijn geen overtuigende aanwijzingen gevonden dat deze curatoren zich op grote schaal door perverse prikkels zouden laten leiden. Daarentegen noemt vrijwel iedere participant in de interviews dat één of meer - niet nader genoemde - collega-curatoren onnodig veel uren steken in bijvoorbeeld de aanpak van onregelmatigheden in een volle boedel of juist werkzaamheden achterwege laten in een lege boedel. Deze situaties worden ook geschetst in de media. ${ }^{57}$ De interviews bevestigen daarmee het beeld dat de bestaande beloningsstructuur curatoren in de praktijk kan aansporen om lege boedels snel en kostenefficiënt af te wikkelen en de onbetaald gebleven uren te compenseren door meer uren te besteden in faillissementen met een volle boedel. ${ }^{58}$

Bij wijze van aanbeveling kan op basis van de resultaten de vraag worden gesteld of de huidige beloningsstructuur van de curator nog passend is, zeker als van hem een rol in de aanpak van onregelmatigheden wordt verlangd. De lege-boedelproblematiek is een onderwerp dat al geruime tijd in de belangstelling staat en een oplossing verlangt. ${ }^{59}$ Onzes inziens is het niet te verantwoorden dat het gebrek aan adequate beloning in sommige faillissementen kan worden gecompenseerd met andere - goed gevulde - faillissementen, want zo worden de schuldeisers van de faillissementen met een behoorlijke boedel benadeeld.

\section{- De afhankelijkheidsrelatie tussen de rechter-commissaris en de curator}

De resultaten van de interviews geven ten slotte inzicht in de afhankelijkheidsrelatie tussen de rechter-commissaris en de curator. ${ }^{60}$ Vrijwel alle curatoren geven aan dat zij door het gebrek aan een transparant benoemingsbeleid druk ervaren om te handelen zoals de rechtbank wenst. ${ }^{61}$ Het is voor curatoren echter niet altijd duidelijk wat de rechtbank van curatoren verwacht, aangezien rechterscommissarissen ieder hun eigen idee hebben over wat een 'goede' afwikkeling van een faillissement is en bovendien met enige regelmaat rouleren buiten de insolventieafdeling. De interviews laten zien dat niet in ieder arrondissement periodieke evaluatiegesprekken aan de hand van een aantal criteria worden gevoerd

56 Zie ook Hilverda 2014, p. 12; Van Dijck e.a. 2008.

57 Zie bijv. De Boeck 2020; Polman 2020; Mijnheer 2015.

58 Zie ook Van Dijck \& Gramatikov 2010; Van Dijck e.a. 2008.

59 Zie ook Schreurs 2020.

60 Zie voor vergelijkbare resultaten: Hollemans \& Van Dijck 2020.

61 Zie ook Wessels 2013. 
zoals is aangegeven in het Recofa-benoemingsbeleid. ${ }^{62}$ Indien er wel een evaluatiegesprek wordt gevoerd, hebben curatoren het idee dat er niet goed wordt gekeken naar ingediende documenten, waardoor individuele feedback ontbreekt. De enige bekende objectieve beoordelingscriteria zijn de door de rechtbanken opgestelde KPI's. Indien curatoren afgaan op KPI's, worden zij gestimuleerd om faillissementen zo kostenefficiënt mogelijk af te wikkelen. Deze stimulans draagt weer bij aan de bestaande praktijk om minder uren te steken in lege boedels en meer uren te steken in volle boedels, zodat er een positieve balans bestaat tussen gemaakte kosten en (gerealiseerde) boedelomvang. Deze criteria moedigen curatoren tevens aan om minder uren te steken in de aanpak van onregelmatigheden wanneer er geen uitzicht bestaat op verhaalsmogelijkheden. Ook de wens van rechtbanken om faillissementen voortvarend af te wikkelen - dat wil zeggen binnen drie jaar - kan een belemmering vormen voor het signaleren en redresseren van onregelmatigheden.

Bij wijze van aanbeveling merken wij op dat nader onderzoek - niet het minst onder rechters-commissarissen - inzicht kan bieden in de wijze waarop invulling kan worden gegeven aan de relatie tussen de rechter-commissaris en de curator. Hieronder valt ook de vraag of rechters-commissarissen curatoren kunnen stimuleren om onregelmatigheden consequent aan te pakken door dit aspect specifiek op te nemen in de beoordeling van curatoren. Gezien de afhankelijkheidsrelatie is het onze verwachting dat curatoren aanwijzingen van de rechters-commissarissen zullen opvolgen.

\section{Slot}

De wetgever verwacht dat de curator bijdraagt aan de aanpak van onregelmatigheden door onregelmatigheden consequent te signaleren en redresseren, maar aan de daadwerkelijke inzet van de curator kan gelet op de kritiek vanuit de faillissementspraktijk worden getwijfeld. De resultaten van onze kwantitatieve studie laten zien dat de curator geconstateerde onregelmatigheden inderdaad niet in ieder faillissement redresseert. Zo is de curator minder geneigd te redresseren indien er twijfels zijn over verhaalsmogelijkheden, al is het gevonden effect van gebrek aan verhaalsmogelijkheden op de redresseringsbeslissing van de curator beperkt. De resultaten van de kwalitatieve studie bevestigen dat er ook andere verklaringen bestaan die gezamenlijk maken dat curatoren onregelmatigheden niet consequent aanpakken.

De belemmeringen die curatoren ervaren, laten zien dat de bezwaren van de curatorenpraktijk voorafgaand aan de invoering van de Wet versterking curator niet ongegrond zijn. De resultaten geven aanleiding om te twijfelen aan het rendement en de preventieve werking van rol van de curator bij de aanpak van onregelmatigheden. We hebben verschillende aanbevelingen gedaan om tegemoet te komen aan de bezwaren van curatoren en zo curatoren meer te faciliteren bij de aanpak van onregelmatigheden. 


\section{Referenties}

Bentfort van Valkenburg, H.M.D. \& J.H.M. van de Wiel, 'De faillissementscurator en vrijheid', MvV 2020(7.5), p. 267-272.

Boeck, R. De, 'De een zijn dood... Curatoren doen aan gelegaliseerde necrofilie', www.quotenet.nl, 25 september 2020.

Boeije, H., 'A purposeful approach to the constant comparison method in the analysis of qualitative interviews', Quality \& Quantity 2002(36), p. 391-409.

Boer, D. \& V. Lalta, Faillissementen: oorzaken en schulden 2010, Den Haag: CBS 2011.

Boon, R.A. e.a., Recofa-uitgangspunten bij de benoeming van curatoren en bewindvoerders in faillissementen en surseances van betaling, www.rechtspraak.nl, 15 maart 2013.

Borrius, Y., 'Schending publicatieplicht: bewijsvermoeden te beteugelen?', in: P.W. Schreurs e.a. (red.), De Gereedschapskist van de Curator. Insolad Jaarboek, Deventer: Wolters Kluwer 2015, p. 23-48.

Bowen, G.A., 'Grounded Theory and Sensitizing Concepts', International Journal of Qualitative Methods 2006(5), p. 12-23.

Cohen, J., Statistical power analysis for the behavioral sciences (2nd ed.), New Jersey NY: Lawrence Erlbaum 1988.

Dijck, G. van e.a., 'Lege boedels: code rood of vals alarm?', TvI 2008(33), p. 210-220.

Dijck, G. van \& M.A. Gramatikov, 'De beloning van curatoren empirisch onderzocht', TvI 2010(2).

Elswijk, D.A. van e.a., Faillissementen. Oorzaken en schulden 2015, Den Haag: CBS 2016.

Enckevort, C.V. van, 'De curator als private partner van het Openbaar Ministerie?', $\mathrm{Tv} C \mathrm{Cu}$ 2016(1), p. 13-21.

Feenstra, R.F., 'De rechten en verplichtingen van de gefailleerde: is de wetgever het spoor bijster?', in: R.F. Feenstra e.a. (red.), De Curator en de Failliet. Insolad Jaarboek, Deventer: Wolters Kluwer 2019, p. 267-286.

Franken, M.J.M. e.a., INSOLAD Rapport Beloning Curatoren 2008, via https:// static.basenet.nl/cms/105928/Publicaties/9789013061154_Rapport\%20beloning \%20curatoren_BW.pdf.

Harmsen, C.M., 'Artikel 2:248 lid 2 BW: botte bijl of vlijmscherp mes?', in: P.W. Schreurs e.a. (red.), De Gereedschapskist van de Curator. Insolad Jaarboek, Deventer: Wolters Kluwer 2015, p. 49-74.

Hees, A. van, 'Het doel van het faillissement en de taak van de curator', TvI 2004(45), p. 200 e.v.

Hilverda, C.M., De bestrijding van faillissementsfraude. Waar een wil is..., Deventer: Wolters Kluwer 2012a.

Hilverda, C.M., 'De economische malaise: een zegen voor de faillissementsfraudebestrijding?!', NJB 2012b-175(2), p. 185-191.

Hilverda, C.M., 'De aanpak van faillissementsfraude. De stand van zaken', TBS\&H 2014(1), p. 9-16.

Hollemans, R. \& G. van Dijck, 'Een empirische studie naar toezicht door rechters(-commissarissen) op curatoren in de praktijk', TvI 2020(10), p. 68-76.

Keijzer, F.E., 'Het Wetsvoorstel civielrechtelijk bestuursverbod: een placebo met bijwerkingen', Ondernemingsrecht 2015(30), p. 173-179.

Kloe, H.J. de, 'Belangenpluralisme in faillissement', RMThemis 2020(3), p. 134-141.

R. Knegt, A.M. Beukelman, J.R. Popma, P. van Willigenburg \& I. Zaal, Fraude en misbruik bij faillissement: een onderzoek naar hun aard en omvang en naar de mogelijkheden van bestrijding, Amsterdam: Hugo Sinzheimer Instituut (i.s.m. WODC) 2005. 
Lennarts, M.L., 'Boeven vangen op kosten van de boedel? De curator als hoeder van het algemeen belang? Geen goed plan!', TvI 2013(25), p. 137-139.

Lieferink, K., De rol van de curator in de strijd tegen faillissementsfraude. De invloed van de Wet versterking positie curator op het aantal meldingen van vermoedens van faillissementsfraude bij het Centraal Meldpunt Faillissementsfraude (afstudeerscriptie NTI - niet gepubliceerd), 2020.

Luttikhuis, A.P.K. \& R.E. Timmermans, Insolventierecht in cijfers en modellen: schuldeisersbenadeling en conclusies, Den Haag: Boom Juridische uitgevers 2007.

Male, J. van, 'Methoden en technieken in kwalitatief onderzoek', KWALON 2011(16), p. 6-13.

Mijnheer, D., 'Het extreme verdienmodel van curatoren', www.ftm.nl, 26 september 2015.

Nagelkerke, N.J.D., 'A note on a general definition of the coefficient of determination', Biometrika 1991-78(3), p. 691-692.

Nielen, W.J.B. van, 'Versterk de civielrechtelijke fraudebestrijding door de curator!', TBS\&H 2016(3), p. 125-127.

Nielen, W.J.B. van, 'De Wet versterking positie curator: financiering, het fraudespreekuur en nemo tenetur beginsel!', FIP 2017-168(3), p. 39-44.

Nielen, W.J.B. van \& C.M. Derijks, 'De curator als civiele fraudebestrijder', TBS\&H 2014(1), p. 25-36.

Poelen, I., "Verhalenvertellers" als informanten: obstakel of waardevolle bron', KWALON 2017(3), p. 24-28.

Polman, J., 'Curatoren Imtech en topadvocaten De Brauw clashen over "graaigedrag"', https://fd.nl, 2 november 2020.

Remmers, N. \& E. Groenland, 'De steekproeftrekking en de selectie van respondenten in commercieel kwalitatief onderzoek', KWALON 2006(3), p. 21-26.

Ridder, J. de e.a., Evaluatie Garantstellingsregeling curatoren 2012, Groningen: Pro Facto 2019.

Saldaña, J., The coding manual for qualitative researchers, Londen: Sage 2013.

Schreurs, Ph.W., 'Naar een herverdeling', TvI 2020(14), p. 93-95.

Smaling, A., 'Steekproeven voor generalisatie', KWALON 2014(1), p. 5-13.

Strauss, A. \& J. Corbin, Basics of qualitative research: Techniques and procedures for developing grounded theory (2nd ed), Thousand Oaks, CA: Sage 1998.

Verdaas, A.J., 'Beloning van curatoren en bonuscultuur', TvI 2009-6(30), p. 177-179.

Vermaire, R.M. \& J.M. Luijkx, 'Een curator die steviger in zijn schoenen staat? Over het wetsvoorstel versterking positie curator', FIP 2016(2).

Verstijlen, F.M.J., De faillissementscurator, Deventer: W.E.J. Tjeenk Willink 1998.

Verstijlen, F.M.J., 'Een kwart eeuw curatorenaansprakelijkheid', TvI 2020(20), p. 126-130.

Vriesendorp, R.D., Insolventierecht, Deventer: Wolters Kluwer 2013.

Vriesendorp, R.D., '[**]it happens; then and now', TvI 2017(23), p. 148-159.

Webley, L., 'Qualitative approaches to empirical legal research', in: P. Cane \& H.M. Kritzer, The Oxford Handbook of Empirical Legal Studies, Oxford: Oxford University Press 2010.

Wessels, B., 'Naar een betere waarborging van de onafhankelijkheid van de faillissementscurator', MvV 2013(10), p. 291-295.

Wibier, R.M., Nederlands faillissementsrecht, Deventer: Wolters Kluwer 2018. 